\title{
Characterization of natural HIV-1 Tat and Vpr variants from Northern India
}

\author{
Sneh Lata ${ }^{1,2}$, Vikas Sood ${ }^{1,2}$, Sajad A Dar ${ }^{1}$, Akhil C Banerjea², Shukla Das ${ }^{1}$, VG Ramachandran ${ }^{\text {* }}$ \\ From First International Science Symposium on HIV and Infectious Diseases (HIV SCIENCE 2012) \\ Chennai, India. 20-22 January 2012
}

\section{Background}

HIV-1 Tat \& Vpr are multifunctional and involved in transactivation, cell cycle regulation, MHC-1 modulation etc. Like other HIV genes, Tat and Vpr are subject to variation. Recombination frequency is higher in the first exon of Tat and Vpr. Characterization of these variants is the subject of the present study.

\section{Methods}

HIV-1 Tat exon 1 and Vpr were amplified from the DNA isolated from blood of HIV infected patients and cloned. Clones were got sequenced and aligned against reference sequences using CLUSTAL W. Sim plot analysis was done for recombinants. Their expression was accessed by transfection of HEK 293T cells with myc fusion clones of variants and western blotting using anti-myc antibody. The variant Tat clones were cotransfected with LTR-luc to investigate their LTR transactivation potential by dual luciferase reporter assay.

\section{Results}

Exon 1 of Tat was amplified from 21 samples and $\mathrm{Vpr}$ from 16 samples. Four Tat exon 1 and two $\mathrm{Vpr}$ sequences were found to have unique variations. Among the four unique Tat variants, one resembled subtypes B and $\mathrm{C}$. This recombination in Tat was found to negatively affect its transacivation potential of reference strain B LTR in comparison with native Tat. Two Vpr sequences resembled subtypes $\mathrm{B}, \mathrm{C}$, and $\mathrm{D}$ at different locations. One Vpr variant had a frameshift towards Cterminus.

\footnotetext{
* Correspondence: rama_88@yahoo.com

'University College of Medical Sciences and Guru Teg Bahadur Hospital, Delhi, India

Full list of author information is available at the end of the article
}

\section{Conclusion}

Variations in Tat affect the functional aspects of the protein including interactions with other viral proteins with consequences for virus-host interaction.

\section{Author details \\ 'University College of Medical Sciences and Guru Teg Bahadur Hospital, Delhi, India. ${ }^{2}$ National Institute of Immunology, New Delhi, India.}

Published: 4 May 2012

doi:10.1186/1471-2334-12-S1-P8

Cite this article as: Lata et al:: Characterization of natural HIV-1 Tat and Vpr variants from Northern India. BMC Infectious Diseases 2012 12(Suppl 1):P8.
Submit your next manuscript to BioMed Central and take full advantage of:

- Convenient online submission

- Thorough peer review

- No space constraints or color figure charges

- Immediate publication on acceptance

- Inclusion in PubMed, CAS, Scopus and Google Scholar

- Research which is freely available for redistribution

Submit your manuscript at www.biomedcentral.com/submit
C Biomed Central

\section{Ciomed Central}

